\title{
PEMANFAATAN KEMBALI LIMBAH POTONGAN KAYU MENJADI MATERIAL FURNITURE MELALUI PENDEKATAN SOCIAL ENTREPRENEURSHIP
}

\author{
Senain ${ }^{1)}$ Farida Hanum ${ }^{2)}$ \\ email: senain26@yahoo.com \\ ${ }^{1,2}$ Fakultas Ilmu Sosial dan Ilmu Politik, Universitas Abdurachman Saleh Situbondo
}

\begin{abstract}
One of the excellent products from Situbondo regency is wooden handicraft product so easy furniture business we meet. Waste wood pieces are the remnants of wood pieces in the form of boards or small pieces that can still be seen form. Wooden board consisting of pieces of wood can be utilized into various objects used in the interior of a room. In addition to adding functionality from waste wood pieces, wooden waste board can also add aesthetic value on an object. This is because the board has different characteristics compared to ordinary wooden boards. Activities that have been done include interior design training, interior making from waste wood pieces, Business Management Training and Employee Motivation Program on UKM Meubel Heni and UKM Meubel Kyky. For 6 months the partners' activities are provided with continuous facilitation and training to produce a table of waste wood products and grow entrepreneurial spirit in all partners.
\end{abstract}

Keywords: Waste, meuebel, entrepreneurship

\section{PENDAHULUAN}

Pengembangan UKM perlu mendapatkan perhatian yang besar baik daripemerintah maupun masyarakat agar dapat berkembang lebih kompetitif bersama pelaku ekonomi lainnya. Kebijakan pemerintah ke depan perlu diupayakan lebih kondusif bagi tumbuh dan berkembangnya UKM. Pengembangan UKM melalui pendekatan pemberdayaan usaha, perlu memperhatikan aspek sosial dan budaya di masing-masing daerah, mengingat usaha kecil dan menengah pada umumnyatumbuh dari masyarakat secara langsung. Pemerintah perlu meningkatkan perannya dalam memberdayakan UKM di samping mengembangkan kemitraan usaha yang saling menguntungkan antara pengusaha besar dengan pengusaha kecil, dan meningkatkan kualitas sumber daya manusianya (SDM).

Usaha kecil menengah yang banyak tumbuh di wilayah Situbondo adalah industri kerajinan. Industri kerajinan yang ada di wilayah Situbondo diantaranya; kerajinan batik, kerajinan gerabah, kerajinan berbahan kayu, industri kulit, 


\section{INTEGRITAS : Jurnal Pengabdian}

Vol 2, No 2, Desember 2018

ISSN 2580-7978 (Cetak) ISSN 2615-0794 (Online)

kerajinanberbahan bambu, kerajinan logam, dan berbagai industry makanan tradisional.

Salah satu produk unggulan dari daerah kabupaten Situbondo adalah produk kerajinan kayu. Sebagai daerah pedesaan, potensi daerah Situbondo sangatmendukung berkembangnya industri kerajinan kayu. Perkembangan dalam pengerjaan serta pengolahan kayu berjalan sangat pesat, terlebih karena Indonesia memiliki kekayaan yang luar biasa terhadap aneka jenis kayu. Mengenal material kayu dengan tujuan digunakan dan dimanfaatkan, merupakan hal yang penting, baik bagi pengusaha yang bergerak dalam bidang industri kayu, maupun pemakai kayu lainnya agar dalam pemanfaatannya kayu dapat digunakan secara benar dan maksimal sehingga tidak terjadi pemborosan penggunaan kayu dan pada akhirnya dapat mengurangi dampak buruknya baik pada alam maupun bagi manusia yang menggunakannya.

Dalam pemanfaatan kayu yang dilakukan oleh UKM Mebel, kayu banyak digunakan sebagai material utama pembuatan furnitur serta sebagai bagian dari pondasi bangunan. Dalam pembuatan furniture misalnya, kayu tersebut diolah menjadi potongan-potongan kayu yang disesuaikan dengan bentuk furniture yang akan dibuat. Sisa dari potongan kayu tersebut biasanya berupa potongan kayu berukuran sedang dan kecil yang pada akhirnya hanya dianggap sebagai limbah tidak bermanfaat dan dibuang begitu saja(gambar 1), kemudian berujung menjadi kayu bakar dan asapnya akan menghasilkan $\mathrm{CO}_{2}$ yang dapat mencemari lingkungan.

Setelah proses pemanfaatan kayu tersebut selesai, kemudian muncul masalah lain baik di masyarakatnya sendiri maupun pemanfaatannya kemudian di Interior. Masalah yang muncul di masyarakat adalah mengenai kurangnya pengetahuan masyarakat tentang bagaimana memanfaatkan limbah potongan kayu agar tak terbuang sia-sia dan dapat menjadi ide kreatif yang juga bermanfaat. Sedangkan di Interior sendiri, masalah yang timbul adalah bagaimana limbah potongan kayu tersebut dapat dimanfaatkan secara tepat menjadi bagian dari furnitur maupun elemen pembentuk ruang, sehingga selain bermanfaat dari segi fungsi juga dapat menambah keindahan interior itu sendiri. 


\section{INTEGRITAS : Jurnal Pengabdian}

\section{Vol 2, No 2, Desember 2018}

ISSN 2580-7978 (Cetak) ISSN 2615-0794 (Online)

Proses manajemen yang dilakukan oleh UKM tergolong masih sederhana. Manajer berperan ganda sebagai pemilik usaha dan desainer. UKM ini juga belum memiliki pembukuan yang rapi sehingga pencatatan cash flow yang baik belum dimiliki oleh kedua UKM ini. Modal yang dimilki berasal dari modal pribadi dan ditambah dari pinjaman Bank. Pembukuan yang dilakukan masihsangat sederhana hanya mencakup komponen pembelian bahan, gaji karyawan,dan pendapatan dari penjualan. UKM merasa motivasi kerja karyawan perlu ditingkatkan, sehingga sangat dibutuhkan pelatihan motivasi bagi karyawan. Selain itu peluang training yang dapat dilaksanakan diantaranya training menumbuhkan jiwa kewirausahaan, maintenance mesin, manajemen usaha, desain grafis dan penggunaan internet sebagai media pemasaran.

Tujuan kegiatan ini adalah untuk membentuk UKM Mebeul agar memiliki jiwa kewirausahaan sosial dan motivasi yang kuat dengan memanfaatkan limbah potongan kayu menjadi produk interior yang bernilai jual.

\section{METODE PELAKSANAAN}

Metode pelaksanaan kegiatan Pemanfaatan Kembali Limbah Potongan Kayu Menjadi Material Furniture Dan Elemen Pembentuk Ruang Dalam Interior digambarkan dalam diagram berikut ini berupa solusi yang ditawarkan untuk mengatasi permasalahan yang ada 


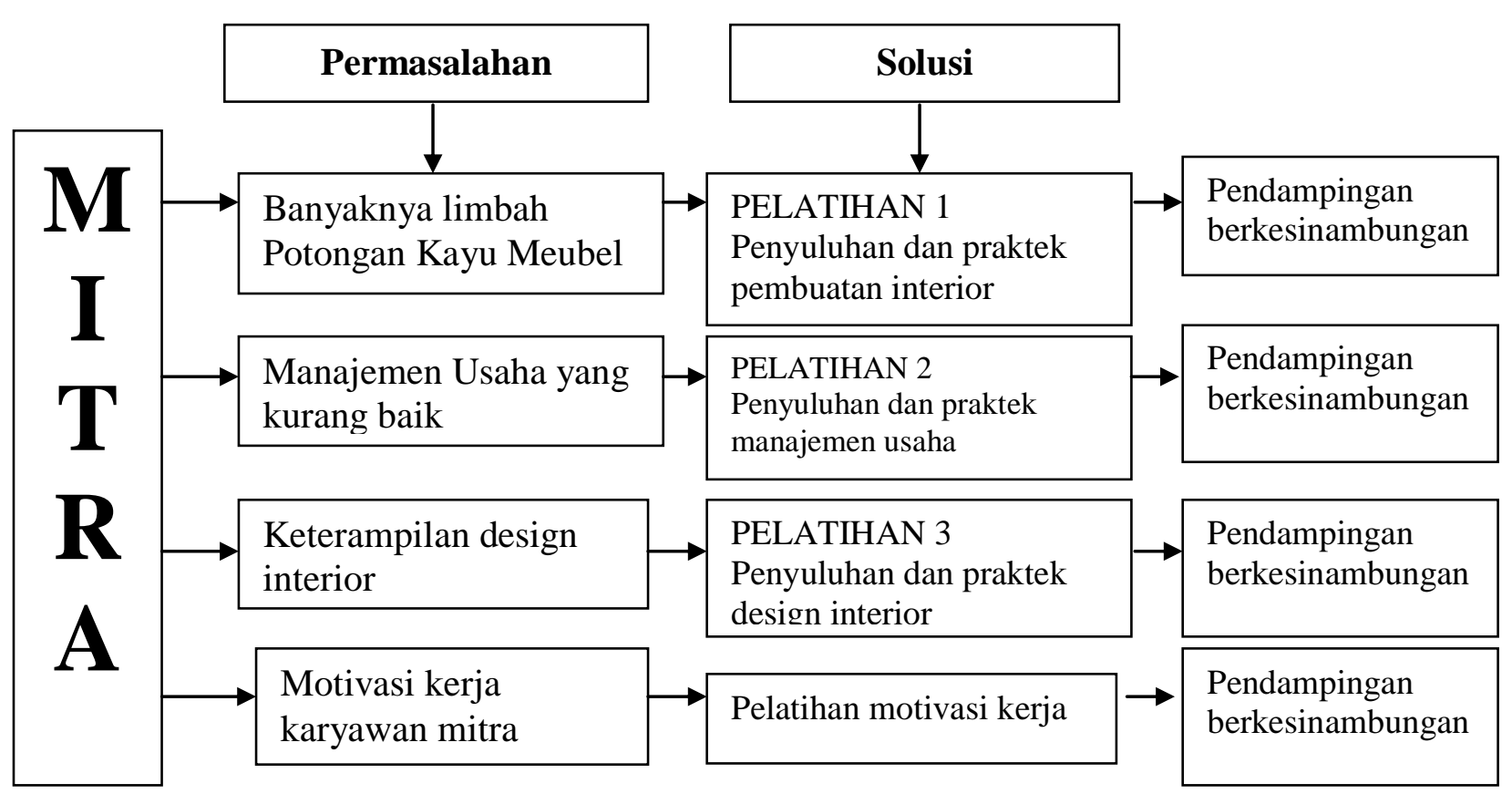

\section{HASIL DAN PEMBAHASAN}

\section{Pelatihan Design Interior}

Kegiatan pelatihan ini diikuti oleh mitra dari UKM Mebel Heni dan UKM Mebel Kyky pada tanggal 19 Pebruari 2017. Gambaran design yang menarik dan dibutuhkan oleh konsumen saat ini dijadikan sebagai materi pelatihan. Pada kegiatan ini peserta langsung membuat design sesuai ide dan kreatifitas peserta dengan pendampingan dari pengabdi. Peserta mengikuti kegiatan ini dengan sangat antusias sehingga target luaran pahamnya peserta/mitra terwujud dengan baik.

\section{Pembuatan Interior Dari Limbah Potongan Kayu}

Berbekal pelatihan yang dilakukan pada 19 pebruari 2017, mitra kembali diberikan pemahaman langsung dengan cara melakukan praktek pembuatan interior dari design yang mereka buat pada 25 Pebruari 2017. Interior yang dibuat adalah meja dari limbah potongan kayu. 


\section{INTEGRITAS : Jurnal Pengabdian}

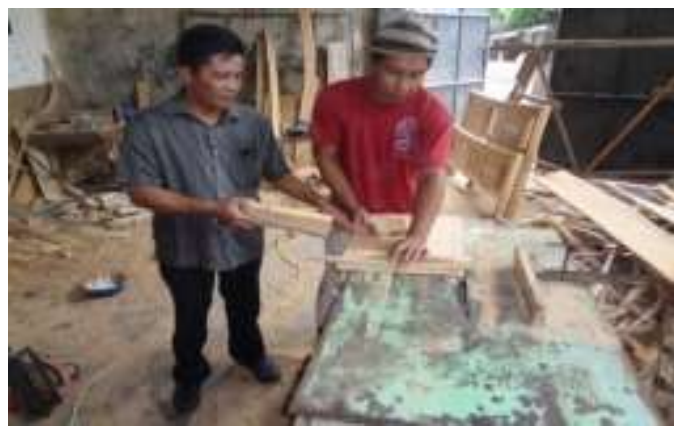

Gambar 1. Proses Pembuatan Meja Dari Limbah Potongan Kayu

Dari kegiatan ini tercapai target luaran berupa produk serta adanya peningkatan pemahaman dan keterampilan masyarakat mitra seperti terlihat pada gambar 2

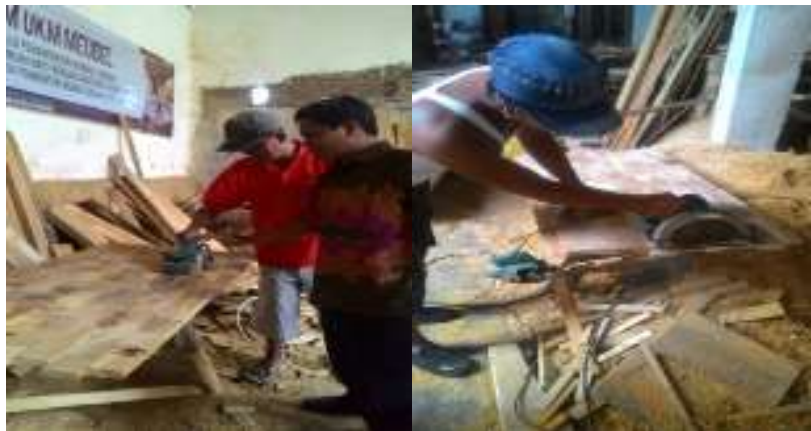

Gambar 2. Proses Pembuatan Meja dari Limbah Potongan Kayu

\section{Pelatihan Manajemen Usaha}

Proses manajemen yang dilakukan oleh kedua UKM tergolong masih sederhana. Manajer berperan ganda sebagai pemilik usaha dan desainer. UKM ini juga belum memiliki pembukuan yang rapi sehingga pencatatan cash flow yang baik belum dimiliki oleh kedua UKM ini. Pembukuan yang dilakukan masih sangat sederhana hanya mencakup komponen pembelian bahan, gaji karyawan,dan pendapatan dari penjualan. Oleh karena itu diperlukan pembenahan sistem administrasi. Sumber daya manusia yang dimiliki oleh UKM Meubel Heni adalah 5 karyawan, dengan kualifikasi pendidikan lulusan SMP,SMA/SMK. Sementara Meubel Kiki memiliki 4 karyawan dengan kualifikasi pendidikan lulusan SMA/SMK. 


\section{INTEGRITAS : Jurnal Pengabdian}

\section{Vol 2, No 2, Desember 2018 \\ ISSN 2580-7978 (Cetak) ISSN 2615-0794 (Online)}

Pada 5 Maret 2017 dilaksanakan pelatihan manajemen usaha untuk memperbaiki manajemen kedua mitra agar dapat membuat pembukuan sehingga pencatatan keuangan dapat diketahui dengan baik oleh owner.

\section{Program Motivasi Karyawan}

Motivasi adalah sebagai energi dan kekuatan seseorang yang akan membangkitkan tingkat antusiasme dan ketekunan dalam melakukan suatu kegiatan atau usaha, baik yang datang dari dalam diri sendiri (motivasi internal) ataupun dari luar individu (motivasi eksternal).

Motivasi ini merupakan tugas dari seorang pimpinan untuk membuat para bawahan atau karyawannya bersemangat melakukan tugas-tugasnya. Motivasi kerja bersumber dari adanya kesempatan untuk maju dan berkembang, dari jenis pekerjaan, serta adanya perasaan bangga diri menjadi bagian dari suatu perusahaan atau tempat seseorang tersebut bekerja. Selain itu, motivasi kerja sangat dipengaruhi oleh perasaan aman dalam bekerja, penghasilan atau gaji yang adil dan kompetitif, kondisi lingkungan kerja yang menyenangkan, penghargaan dan pengakuan atas prestasi kerja, serta perlakuan yang adil dari pimpinan. (Anonim.2017)

Sasaran utama pelatihan ini adalah owner UKM Mebel Kiki dan UKM Mebel Heni. Kegiatan dilakukan pada tanggal 02 April 2017. Luaran yang tercapai adalah karyawan termotivasi untuk lebih produktif menghasillan produk dari limbah potongan kayu sehingga target kuantitas dapat terpenuhi dan kualitas juga turut mengiringi dengan terus dilakukannya pendampingan kepada karyawan untuk terus produktif. Kuantitas dan kualitas akan juga berpengaruh pada motivasi karyawan karena akan ada penghargaan dari hasil kerja berupa upah dan pengakuan atas prestasi kerja.

\section{KESIMPULAN}

Kegiatan yang telah dilakukan hingga saat ini diantaranya Pelatihan design interior, Pembuatan interior dari limbah potongan kayu, Pelatihan Manajemen 


\section{INTEGRITAS : Jurnal Pengabdian}

Vol 2, No 2, Desember 2018

ISSN 2580-7978 (Cetak) ISSN 2615-0794 (Online)

Usaha dan Program Motivasi Karyawan berjalan dengan lancar. Selama 6 bulan kegiatan berlangsung telah diperoleh luaran sesuai target yang direncanakan. Antusias mitra mengikuti kegiatan sehingga adanya pemahaman dan keterampilan masyarakat mitra dalam mengolah limbah potongan kayu menjadi produk berkualitas dengan pendampingan yang berkesinambungan melalui pelatihan yang telah dilakukan.

\section{DAFTAR PUSTAKA}

Anonim.2017. Cara dan Upaya Meningkatkan Motivasi Kerja Karyawan https://pendaftaran-cpns.blogspot.co.id, diakses tanggal 01 Juli 2017

Fakhri,dkk. 2010. Pemanfaatan Sisa Potongan Kayu Olahan Untuk Produk Papan Lantai Komposit. JURNAL APTEK Vol. 3 No. 1 Januari 2010

Purwanto,joko.2011. Pembuatan balok dan papan dari limbah industri kayu Board and wood block making from waste of wood industries. Jurnal Riset Industri Vol. V, No. 1, 2011, Hal. 13-20

Ratniarsih,Ika dkk.2013. Pemanfaatan limbah potongan kayu jati Untuk penyekat ruang non permanen. Simposium Nasional RAPI XII - 2013 FT UMS

Anggriani, Swastika Dhesti,2011. pemanfaatan-kembali-limbah-potongan. http://ecointerior-isi.blogspot.co.id. Diakses tanggal 15 April 2016

Westra, I Made. 1993. Pengetahuan Bahan dan Alat Industri Kerajinan Kayu.JJakarta : Pusat Perbukuan, Depdikbud. 